\title{
BAPTISM, CATECHISM, AND THE ECLIPSE OF JESUS' TEACHING IN EARLY CHRISTIANITY ${ }^{1}$
}

\author{
Alan Kreider
}

\section{Summary}

Which should come first: baptism or teaching? Evidence from the first six centuries indicates that Christians began by giving priority to baptism and then, after the period from the Didache through Augustine in which catechism preceded baptism, they returned to the former order. The early Christians practised intensive catechism. They sought to resocialise pagans into a lifestyle, often rooted in the teachings of Jesus, which was practised by believers. In the fourth and fifth centuries, many catechists came to focus upon belief rather than behaviour, and the teachings of Jesus were increasingly marginalised. After the sixth century, catechism largely disappeared.

\section{Introduction}

Matthew's Gospel ends with a commissioning. The resurrected Jesus, on a Galilean mountain, informed his awe-struck disciples that God has enthroned him as Lord: 'all power in heaven and on earth has been given to me.' Therefore Jesus gave them a task. They were to 'go... and make disciples of all nations, baptising them in the name of the Father and of the Son and of the Holy Spirit, teaching them to observe all that I have commanded you' (Mt. 28:18-20).

This commissioning has reverberated across the centuries; its effect, especially within the past two hundred years, has been immense, and has resulted in the globalisation of Christianity. ${ }^{2}$ But the commissioning also poses many

\footnotetext{
${ }^{1}$ Tyndale Christian Doctrine Lecture, 1996.
}

${ }^{2}$ The Mt. 28.17-20 text was rarely cited in by early Christian writers prior to the later fourth century; see Norbert Brox, 'Zur christlichen Mission in 
questions, of which I shall concentrate upon two. In this commissioning Jesus urged his disciples to make other disciples, and to do so by engaging in two activities which would be aspects of disciple-making-by baptising and by teaching. But is it significant that Jesus mentioned baptising before teaching? Did he mean to establish a procedural order for the initiation of new disciples? Or was this order fortuitous, subject to change according to circumstances? A second question refers to Jesus' injunction to teach people 'to observe all that I have commanded you.' In saying this Jesus, in keeping with the emphases throughout Matthew's gospel, underscored the importance of a lived, practical response to his teachings. Wise people, Jesus observed at the end of the Sermon on the Mount, are those who 'hear these words of mine and act upon them' (Mt. 7:24). But what were the Great Commission's 'things which I have commanded you'? They clearly gave a 'strongly ethical emphasis' to the making of disciples. ${ }^{3}$ Did they also give a privileged place to those other words from a Galilean mountain-the Sermon on the Mount? 4

One can approach these questions from many angles. including exegetically or theologically. I shall examine them from an historical angle, examining the life and practice of the Christians of the early centuries of the Church's history, asking questions about the relationship between baptism and teaching, and noting their effect upon the life of Christians.

\section{The Procedures of Early Catechism and Baptism}

According to the rest of the New Testament there would seem to be little doubt about the approaches which the earliest Christians took to baptism and teaching. There, to be sure, are some mysterious silences. Why, we might wonder, is there no reference to the baptism of Jesus' disciples? But when those

der Spätantike', in Karl Kertelge (ed.), Mission im Neuen Testament, Quaestiones disputate 93 (Freiburg-im-Breisgau: Herder, 1982) 194ff.

${ }^{3}$ R.T. France, The Gospel According to Matthew: An Introduction and Commentary (Leicester: Inter-Varsity Press, 1985) 415.

${ }^{4}$ David J. Bosch, Transforming Mission: Paradigm shifts in Theology of Mission (Maryknoll, NY: Orbis Books, 1991) 69. 
disciples began their discipling of the nations they did so with a clear sense of order. Peter, on Pentecost, summoned those who had been 'cut to the heart' to 'Repent and be baptised' (Acts $2: 38$ ). He did not say, 'Repent, be catechised, and then be baptised.' To be sure, the three thousand who were apparently baptised promptly 'devoted themselves to the apostles' teaching and fellowship'; and their behaviour, as reported in Acts 2 and 4 , indicates that their 'repentance' entailed a lived, practical response to Jesus' good news: they practised radical economic sharing. ${ }^{5}$ We can be less sure about the effects upon lifestyle of the conversions of the Ethiopian eunuch in Acts 8:26-40 and the Philippian jailer and his household in Acts 16:27-34. We may speculate that their lifestyles and praxis were revolutionised, but we do not know. What we do know is that, in the case of all of these, baptism followed immediately upon a confession of Jesus as Lord.

But by the early second century the Christians had changed the order. Our information is of course scanty; and we must in any study of early Christianity assume that there was a variety of practices in the churches scattered across the Roman empire and beyond. But the documents that we do have are clear. In Syria, the famous Didache (7:1) stated, 'This is how to baptise. Give instruction on all these points, and then baptise in running water...'. So prior to baptism there was teaching. Although it is possible to hazard some guesses about its content, we do not know how much teaching there was, or how long it lasted. We do know that there was a prescribed prebaptismal fast for the baptismal candidate of 'one or two days', accompanied by the baptiser and 'any others who can'. In Rome by the middle of the century Justin reports a similar but slightly more elaborate procedure (I Apology 61). Speaking evidently as someone who prepared candidates for baptism, Justin reported that people who were admitted to be baptised

\footnotetext{
5These texts were apparently, already in the book of Acts, used with paradigmatic intent; they certainly functioned as such throughout the early centuries of the Church. See S. Scott Bartschy, 'Community of Goods in Acts: Idealization or Social Reality?' in Birger A. Pearson (ed.), The Future of Early Christianity: Essays in Honor of Helmut Koester (Minneapolis: Fortress Press, 1991) 309-18.
} 
had already been catechised: they had been 'persuaded and believe that the things we teach and say are true.' Not only were they persuaded; they had 'promised that they can live accordingly.' The teachings that were given in Justin's community were assumed to imprint themselves upon the lives and decisions of the members. Following prayer and fasting, in which catechists joined with candidates, the candidates were then 'made new through Christ' in baptism.

So in the first century baptism preceded catechism, but by the second century the procedure had been reversed. Why this change, we might wonder? Contemporaries did not discuss it, at least in writing, but one scholar, Joseph Lynch, has proposed several reasons. Lynch has observed that Christianity's earliest converts were primarily Jews or godfearers who already shared in the Jewish heritage of story, morality and world-view; the second-century converts, in contrast, were ex-pagans who needed a far-reaching programme of instruction and resocialisation. Lynch has also hypothesised that a longer catechetical process as a precondition for baptism was a result of the theological disputes which were present in the second century. ${ }^{6} \mathrm{~A}$ third reason, which Lynch did not mention, had to do with the need, in an age of persecution, of screening out possible spies and informers. ${ }^{7}$ A final possible reason is that pastoral experience indicated that the teachings of Jesus, which the movement was committed to incarnating and practising, were sufficiently strenuous as to require a process of resocialisation on the part of all would-be converts, Jew or Gentile. Whatever the reason, by the end of the second century a catechetical procedure had come into existence-present with variations in both East and West-in which baptism took place only after a catechesis that was both extensive and intensive. 8

6Joseph H. Lynch, Godparents and Kinship in Early Medieval Europe (Princeton: Princeton University Press, 1986) 86-87.

7Origen, Contra Celsum 3.51; Athenagoras, Legatio 1.3; Testamentum Domini 1.36; Canons of Elvira 73.

${ }^{8}$ Adalbert Hamman, 'Catechumen, Catechumenate', in Angelo di Berardino (ed.), Encyclopedia of the Early Church (Cambridge: James Clarke, 
Tertullian is a prime source of the new procedure. In the 190s he reported scornfully of North African gnostics that 'it is doubtful who is a catechumen, and who a believer; they have all access alike, they hear alike, they pray alike...'. Unlike the orthodox, the gnostic 'catechumens are perfect before they are full-taught.' 9 The Church's catechumens, on the other hand, were 'being systematically formed' in a process that would culminate in the baptismal font where they would be 'formed anew by water'. ${ }^{10}$ Several decades later, in writings and homilies emanating from Egypt and Palestine, Origen gave further details. He described Christian leaders who did not, like the philosophers, accept all who wished to enrol for their teaching. Instead, they 'tested them individually beforehand,' examining their souls. Those who surmounted this first hurdle were admitted into a group of catechumens who had 'devoted themselves sufficiently to the desire to live a good life' and were willing to submit to a regimen of catechesis. When, after a period of training, some of these were ready to commit themselves 'to desire nothing other than those things of which Christians approve' and to proceed to baptism, then the leaders appointed others to examine yet again their 'lives and conduct.' These commitments had implications for lifestyle that were so far-reaching that Origen likened the entry into the catechumenate to the Israelites crossing the Red Sea. Already the catechumens, although not yet in the promised land of the baptised, were experiencing the freedom of the wilderness. ${ }^{11}$

1992) vol. 1, 151-52; Joseph A. Jungmann, 'Catechumenate', in New Catholic Encyclopedia (New York: McGraw-Hill, 1967) vol. 3, 238-40.

${ }^{9}$ Tertullian, De Praescriptione Haereticorum 41.

10Tertullian, De Baptismo 1, 3.

${ }^{11}$ Origen, Contra Celsum 3.51; Homily on Joshua 4.1; Homily on Exodus 6.6; Homily on Luke 22.5. Neither F.X. Funk (Kirchengeschichtliche Abhandlungen, I [Paderborn: Ferdinand Schöningh, 1897] 234), who contended that the sign that they have been purified' was baptism, nor Eduard Schwartz ('Bußstufen und Katechumenatsklassen', in idem, Gesammelte Schriften zum Neuen Testament und zum frühen Christentum [Berlin: Walter De Gruyter, 1962] vol. 5, 238-41), for whom it signifies a movement from 'hearer' to 'catechumen' stage, seems to have it right. Origen elsewhere does not refer to 'hearers'; and the meaning here seems to be the move from the general run of catechumens to those who are receiving final preparation 
The fullest report of the catechetical procedures comes from one of the most enigmatic documents at our disposal, the Apostolic Tradition which appears to reflect third-century Western practice. ${ }^{12}$ The Apostolic Tradition, like Origen, records the life of Christian communities which were very deliberate in their approach to incorporating new members. ${ }^{13}$ When candidates for the catechumenate came before the community's teachers, the teachers interviewed the sponsors who had brought them and scrutinised the candidates. Their question was 'whether [the candidates] were capable of hearing the word.' They examined their motivation, their marital status, and their craft or profession. If a candidate was in one of the prohibited professions-for example, a brothel-keeper, a charioteer who competed in the games, or someone who had 'the power of the sword' or 'was a magistrate of a city who wears the purple' - they were to quit their jobs or be rejected. The assumption seems to have been that only people who lived

for baptism. In his Homily on Luke 32.6, Origen lists all who were present: 'catechumens and faithful, women, men and children', but no 'hearers'.

${ }^{12}$ For editions, see Gregory Dix (ed.), The Treatise on the Apostolic Tradition of St Hippolytus of Rome, rev. Henry Chadwick (London: SPCK, 1968); Bernard Botte (ed.), La Tradition apostolique de Saint Hippolyte: Essai de reconstitution, 5th ed. (Münster: Aschendorff, 1989). I have used the English version of G.J. Cuming, Hippolytus: A Text for Students, Grove Liturgical Study, 8, rev. ed. (Bramcote, Notts: Grove Books, 1987). For recent interpretations, with varying views on location and date, see Marcel Metzger, 'Nouvelles perspectives pour la prétendue Tradition apostolique', Ecclesia Orans 5 (1988) 241-59; idem, 'Enquêtes autour de la prétendue "Tradition apostolique", Ecclesia Orans 9 (1992) 7-36; Paul F. Bradshaw, The Search for the Origins of Christian Worship: Sources and Methods for the Study of Early Liturgy (London: SPCK, 1992) 89-92. Professor Bradshaw is leading a team of scholars who are preparing a multi-columned edition of the variants in Latin, Sahidic, Arabic, and Ethiopic of the Apostolic Tradition for the Hermeneia series. For a summary of Bradshaw's current views, see Maxwell E. Johnson, 'The Postchrismational Structure of Apostolic Tradition 21, the Witness of Ambrose of Milan, and a Tentative Hypothesis Regarding the Current Reform of Confirmation in the Roman Rite', Worship 70 (1996) 21-23. For another recent approach, see Allen Brent, Hippolytus and the Roman Church in the Third Century: Communities in Tension Before the Emergence of a Monarchical Bishop (Leiden: Brill, 1995).

${ }^{13}$ The following paragraphs are based upon Apostolic Tradition chapters 15-21, except where otherwise indicated. 
in keeping with the fundamental values of the community could comprehend its teaching. Once they had become catechumens, they had become 'liminal persons', persons 'on a journey from the centre of the city, so to speak, to its fringes.' 14 And this process could last years. Even if the three year requirement is a (late third century?) emendation to the Apostolic Tradition, 15 it is clear that catechetical process would take a long time. Churches elsewhere assumed this: Origen's Biblical instruction of catechumens in Palestine proceeded systematically, and could not have been brief; 16 and the synod of Elvira in early fourth-century Spain recorded a five-year catechumenate. ${ }^{17}$ However long the catechetical period might be, the vital thing was transformation: as the Apostolic Tradition puts it, 'if a man is keen, and perseveres well in the matter, the time shall not be judged, but only his conduct.'

Perseverance was important, because the catechetical process was demanding. In the community of the Apostolic Tradition, as in Origen's Palestine, it was daily, an hour's teaching before work. ${ }^{18}$ The burden of this exertion was lightened somewhat by the presence of other members of the community who shared in these exertions: the catechumens were accompanied as often as possible by their sponsors and other believers who would serve as examples for them. ${ }^{19}$ The candidates 'felt that they were exploring a deep mystery, step by step. They were advancing with a group of fellow explorers along a route which required a high moral effort.' 20 They also were accompanied by their teacher. The catechists could be a 'cleric or a layman'; sometimes they were young and at times they were among the most mature and wise members of the community. Clement of Alexandria urged the rich man

14Thomas M. Finn, 'Ritual Process and the Survival of Early Christianity', Journal of Ritual Studies 3 (1989) 71.

15Hamman, 'Catechumen', 152.

16John Clark Smith, 'Conversion in Origen', Scottish Journal of Theology 32 (1979) 230.

${ }^{17}$ Council of Elvira ch. 11.

18Origen, Homily on Luke 38.6; Homily on Joshua 4.1.

${ }^{19}$ Apostolic Tradition 41.

20Robin Lane Fox, Pagans and Christians (San Francisco: Harper \& Row, 1986) 317 . 
addicted to his wealth to 'set over thyself some man of God as a trainer and governor...' ${ }^{21}$ Origen clearly functioned in this way, establishing a personal, intimate relationship with his hearers. And the impact of his person upon them was profound.22 As Gregory of Pontus put it, 'He exhorted us by his actions and incited us more by what he did than by what he said.'23 The success of the catechist, and of the catechetical process, would be measured when, sooner or later, each candidate would be scrutinised again. 'Let their life be examined,' the Apostolic Tradition enjoined. 'Have they lived good lives when they were catechumens? Have they honoured the widows? Have they visited the sick? Have they done every kind of good work?' If their sponsors could affirm that they have lived in this way, then, it pronounced, 'let them hear the gospel.'24

From this time forward, in the final weeks prior to their baptism, the candidates received daily instruction in Christian belief; very possibly a local creed was the core of their doctrinal catechesis. ${ }^{25}$ They also received a daily exorcism to see whether 'the Alien' was continuing to lurk. All of this reached a peak of excitement in the cathartic rituals of the Easter vigil. The bishop laid his hands upon them, exorcised them a final time and breathed in their faces; then the candidates were disrobed and anointed. Naked, their 'secular socialisation' was dismantled. They left behind their 'lifelong accumulation of secular interests, values and loyalties' $; 26$ they renounced Satan; then they were thrice immersed as they confessed their faith in the

${ }^{21}$ Clement of Alexandria, Quis Dives salvetur? 41.

22Robert Wilken, 'Alexandria: A School of Training in Virtue', in Patrick Henry (ed.), Schools of Thought in the Christian Tradition (Philadelphia: Fortress, 1984) 19-23.

23 Panegyric on Origen 9.

${ }^{24}$ Apostolic Tradition 20.

25It seems unlikely, pace Pierre Nautin (Origene: Sa vie et son oetıvre, Christianisme Antique 1 [Paris: Beauchesne, 1977] 395), that only at that point would the catechumens begin to hear the reading of the Gospels; these were read and expounded on Sundays before the exclusion of the catechumens.

${ }^{26}$ Margaret R. Miles, Carnal Knowing: Female Nakedness and Religious Meaning in the Christian West (Boston: Beacon Press, 1989) 44. 
Father, Son and Holy Spirit. They ascended from the water to be clad anew, whereupon the bishop anointed them yet again and signed them with the cross. Finally they were incorporated as brothers and sisters in a new family that prayed together, that exchanged the kiss of peace, and that ate together at the Lord's table. The destination so long desired had been reached; the newly born (neophyte, infant) was the member of a new family, a new nation. ${ }^{27}$

So the candidates had been taught before they were, at long last, baptised. What had they been taught? This of course depended upon what community they were in, and at what period of time. The next section examines the development of early Christian catechism.

\section{The Catechetical Regimen: Resocialisation, Life Change and Teaching}

A number of scholars have commented that, in the New Testament texts themselves, early catechetical traditions are embedded which rephrased the sayings of Jesus and applied them to various Christian communities. 28 The same process was at work in the second century. ${ }^{29}$ The 'maxims' of the community of the Didache, for example, contain some interesting formulations of the words of Jesus: 'Bless those who curse you, and pray for your enemies. Moreover, fast for those who persecute you.' The outline catechesis that follows is practical and earthed in everyday life, sketching in the contours of the 'way of life' which those who were to be baptised were expected to lead. ${ }^{30}$ In Justin's 'house-school congregation' 31 in

27Tertullian, De Baptism 20.

${ }^{28}$ C.E.B. Cranfield, The Epistle to the Romans, International Critical Commentary (Edinburgh: T. \& T. Clark, 1979) vol. 2, 645; Victor Paul Furnish, The Love Command in the New Testament (London: SCM Press, 1973) 106; Walter Wink, Engaging the Powers (Minneapolis: Fortress Press, 1993) $185-86$.

${ }^{29}$ Alan Kreider, Worship and Evangelism in Pre-Christendom, Alcuin/GROW Joint Liturgical Study 32 (Cambridge: Grove Books Ltd, 1995) 11n.

30Didache 1.2-4.14.

${ }^{31}$ Brent, Hippolytus and the Roman Church, 455. 
Rome the teaching to which those who were had given assent was directed at the major addictive concerns of Roman society-sexual adventure, the magic arts, accumulation as opposed to sharing of wealth, xenophobia and hatred of enemies. According to Justin, this teaching was an expression of 'the fair commands of Christ... [whose] sayings were short and concise, for he was no sophist, but his word was the power of God.' Justin then proceeded to spell out the implications of Jesus' teachings which would be taught to those seeking baptism:

About continence he said this... That we should share with those in need and do nothing for [our] glory he said these things... About being long-suffering and servants to all and free from anger, this is what he said. ${ }^{32}$

Justin's Apology is filled with the sayings of Jesus which shaped the life of the Christian community in Rome. Indeed, according to Justin, the point was not to master a body of teaching but to put it into practice: 'Those who are found not living as he taught should know that they are not really Christians, even if his teachings are on their lips...'.33 Baptism would only be accorded to those who were committed to 'live as Christ handed down to us.' 34

Justin, to be sure, imparted the moral teachings of the Christian community within a broad framework of the community's convictions about God and his work in Jesus Christ; an important part of his apologetic was designed to show that Jesus is the fulfilment of prophetic prediction. This salvation-historical backdrop was developed by Irenaeus of Lyons in the late second century. His Demonstration of the Apostolic Preaching is a catechetical work which places the work of Christ in broad perspective. ${ }^{35}$ It does not spend a lot of time on 'the commands of God'; perhaps in this way it anticipates

\footnotetext{
32Justin, 1 Apology 14-17.

33Ibid., 16.

34 Ibid., 66.

${ }^{35}$ Everett Ferguson, 'Irenaeus' Proof of the Apostolic Preaching and Early Catechetical Tradition', Studia Patristica 18.3 (1989) 119-40.
} 
fourth-century trends. ${ }^{36}$ But it demonstrates how the teachings of Jesus which have transcended the Law and have transformed the church's life fit into the 'economy' of God's salvific work from creation to last judgement.

For no longer shall the Law say, Do not commit adultery, to him who has no desire at all for another's wife... nor an eye for an eye and a tooth for a tooth, to him who counts no man his enemy, but all men his neighbours, and therefore cannot stretch out his hand at all for vengeance. It will not require tithes of him who consecrates all his possessions to God, leaving father and mother and all his kindred, and following the Word of God. 37

By the time we get to Origen, the most notable catechist in Alexandria and Caesarea in the first half of the third century, salvation history had come to be the heart of the church's catechetical activity, or at least that aspect which was most thoroughly recorded. In his daily catechetical sessions Origen patiently taught his way through Old Testament books; in his Sunday homilies he catechised upon the gospels. Origen of course did not limit himself to commenting upon the Old Testament narratives; he discoursed freely upon the inner significance of events of salvation history and their fulfilment in Christ, for this history was the source of the community's self-identity. Origen could assume that those who were listening to him, as those who had 'been received into the number of the catechumens... had begun to obey the commandments of the Church.' 38 But the practice of these commandments needed to be encouraged, for he knew that no catechumen could cross the Jordan in baptism without 'changing his conduct and habits,' thereby 'showing the fruits

36Everett Ferguson, 'Catechesis and Initiation', a paper given to the Missiology of Western Culture Colloquium, The Origins and Spread of Christendom in the West, Paris, September 1996; publication forthcoming. 37Demonstration of the Apostolic Preaching, 96. Irenaeus here show how the lifestyle of Christians has been transformed through Christ: Ex. 20.15 has been fulfilled in Mt. 5.21-22; Ex. 21.24 in Mt. 5.38, 44-48; Lv. 27.30 in Mt. 19.27-29.

38 Origen, Homily on Joshua 4.1. 
worthy of conversion.'39 But Origen's catechetical homilies do not deal with the practicalities of Christian formation. How, we might wonder, did the catechists of Alexandria give the catechumens practical help to change their habits?

Possible light on this question may come from the experience of Cyprian, who became a Christian just before the middle of the third century in Carthage. Cyprian was one of the province's high-flyers, an aristocrat of outstanding rhetorical gift. But Cyprian increasingly found the lifestyle of his pagan aristocratic class to be unsatisfying-'darkness and gloomy night,' he called it. 40 Through Caecilianus, a Christian whom he admired, Cyprian was introduced to the Christian community.41 But the Christians lived in ways that fundamentally challenged his values, and they seemed to find a freedom in their deviance that had eluded him. How does one change? How does one give up assumptions and habits which 'have become deeply and radically engrained within us'? Cyprian examined his life-his enjoyment of 'liberal banquets and sumptuous feasts;' his love for glittering attire of gold and purple; his enjoyment at being surrounded by admirers who deferred to him; his ambition-and found this to be bondage. But how does one, in whom the old ways are 'parts of me, indigenous to me', change? How does one become a person of simplicity, equality, humility? How does one become a Christian?

We do not know the details of Cyprian's story. We may legitimately assume that his friend Caecilianus brought him to the catechists of the church of Carthage to be made a catechumen. But what was he taught there? The range of the topics dealt with by catechists after Cyprian became bishop is provided in the three books of his Ad Quirinum, and he may

${ }^{39}$ Origen, Homily on Luke 22.5, 8.

${ }^{40}$ This account, except where indicated, is based on Cyprian's Ad Donatum 3-4. Maurice Wiles has queried the historicity of this account ('The Theological Legacy of St Cyprian', Journal of Ecclesiastical History 14 [1963] 140-41); he has been answered, convincingly in my view, by Elisabeth Fink-Dendorfer, Conversio: Motive und Motivierung zur Bekehrung in der Alten Kirche, Regensburger Studien zur Theologie 33 (Frankfurt-am-Main: Verlag Peter Lang, 1986) 39-45.

${ }^{41}$ Pontius, Vita Cypriani 4. 
have prepared this to provide the catechist Quirinus with scriptural citations on areas the church taught about.42 Might this work indicate the kind of teachings that Cyprian himself encountered as a catechumen? After Books 1 and 2 in which he dealt with salvation history and Christology, in Book 3 Cyprian set forth 120 'maxims of the Lord' which he labelled 'the religious teaching of our school'. It is notable that many of these maxims were ones that the catechumen Cyprian himself had struggled with. The first, drawing upon 36 biblical passages, of which eleven were from Jesus, emphasised simplicity and sharing ('the benefit of good works and mercy'); the second emphasised care for the poor; and the third enjoined that 'charity and brotherly affection are to be religiously and steadfastly practised.' Further maxims dealt, inter alia, with mutual aid, with 'too great lust of food,' with 'the lust of possessing, and money, [which] are not to be sought for,' and with visiting the sick (ch. 9, 60, 61, 109). Believers should be distinctive; they 'ought not to live like the Gentile' (ch. 34). And the standard of their distinctiveness was Jesus Christ: 'there is given to us an example of living in Christ' (ch. 39). If such teachings were a part of the catechesis which Cyprian encountered, they may have increased his ambivalence-his attraction to a vision of life which had now been spelled out to him, and also his sense of being trapped by 'my clinging vices.' And yet, it is reported that as a catechumen Cyprian was changing: he was accustomed, unlike other aristocrats, to 'love' the poor. 43 Furthermore, his friendship with his sponsor Caecilianus may also have helped to encourage him and provide perspective as he sought reformation.

According to Cyprian, what made the decisive difference for him was baptism. In his Ad Donatum, Cyprian does not report the exorcisms that were most probably a part of baptismal preparations. ${ }^{44}$ What he did report as life-changing

${ }^{42}$ Antonio Quacquarelli, 'Note retoriche sui Testimonia di Cipriano', Vetera Christianorum 8 (1971) 204, cited by Everett Ferguson, 'Catechesis and Initiation'.

43 Pontius, Vita Cypriani 6.

${ }^{44}$ Cyprian reported that 'the devil is scourged, and burned, and tortured by exorcists' (Ep. 75 [69].15). 
was 'the help of the water of new birth' and, after that, 'the agency of the Spirit breathed from heaven.' Through the Carthage church's ritual of immersion and anointing Cyprian experienced washing and empowerment. 'In a wondrous manner,' he reported, '...what before had seemed difficult began to suggest a means of accomplishment, what had been thought impossible, to be capable of being achieved;... All of our power is of God; I say, of God.' Cyprian had become a Christian who before long would lead his community in life and death.

So the early Christians expected catechumens to behave like Christians before they had received 'new birth' in baptism; according to the Apostolic Tradition they were even expected to behave like Christians before they have 'heard the gospel.' 45 This may seem perverse to us. It may appear to be a reversal of psychological or theological logic. First one experiences, then one acts; one thinks, ergo one acts. And the Bible would seem to underline this. In both Testaments we encounter a repeated summons to newness of life in response to the prior acts of God. 46 The Christians of the early centuries occasionally stated this vision as well. 47 But from the Didache onwards they added a different perspective. For them the experience of salvation came within the context of their commitment to join with others in living in a transformed way. They sensed that only people who had committed themselves to follow Jesus could understand that his teaching and way are practicable; only people who were already being changed by the good news could understand it. They did not think their way into a new life; they lived their way into a new kind of thinking. 48

${ }^{45}$ Apostolic Tradition 20.

46Outstanding examples include Dt. 24.17-18; Mt. 18.21-35; Eph. 4.32-5.2.

${ }^{47}$ E.g., Didascalia Apostolorum 5.5.

48Richard Rohr, Simplicity: The Art of Living (New York: Crossroad, 1991) 59. 


\section{Living the Teaching of Jesus}

In our examination of the initiation procedures of the early Christians we have observed that catechism almost invariably preceded baptism. ${ }^{49}$ Formed by their catechetical regimen and empowered by their baptismal rituals, the early Christians were concerned to impart and live the teachings of Jesus. We would like to know more about how they taught and inculcated these. Origen reported, for example, of his community that 'they have been taught not to defend themselves against their enemies.' 50 Were they taught in his catechetical homilies, or more likely in supplementary sessions for catechumens? The Syrian Didascalia Apostolorum indicated that it taught 'those who are young in the faith, and the hearers' how to confess their faith when interrogated and how to endure when suffering. ${ }^{51}$ It does not say how, and we may never know. What we do know is that the focus of innumerable Christians across the Roman empire was upon Jesus.52 To be sure, their focus was not generally upon the stories which Jesus told. It was rather upon his life, which called forth a response of imitation. ${ }^{53}$ Furthermore it was upon Jesus as teacher, the 'lawgiver' who imparted 'precepts' and 'maxims', 'powerful words,' 'incisive words', words of 'charm'.54 And these precepts and words changed people and gave them a deep inner confidence. The pagan Celsus reported

${ }^{49}$ For a curious exception, the only one known to me, see John Barns and Henry Chadwick, 'A Letter Ascribed to Peter of Alexandria', Journal of Theological Studies n.s., 24 (1973) 454.

50Origen, Contra Celsum 3.8.

${ }^{51}$ Didascalia Apostolorum 5.5.

52I do not think that the evidence supports Professor Ramsay MacMullen, who finds in the pre-Christendom Christians a 'very unsteady focus on the role of Jesus' (Christianizing the Roman Empire (A.D. $100-400$ ) [New Haven: Yale University Press, 1984] 21).

53Ignatius of Antioch, Phil 7.2; Justin, 1 Apol 10; Clement of Alexandria, Paedagogus 1.12; Didascalia Apostolorum 5.5; Cyprian, Ad Quirinum 3.39; Origen, Homily on Jeremiah 4.5-6.

${ }^{54}$ Aristides, Apol 15; Athenagoras, Legatio 11.2; Tertullian, De Patientia 6; Clement of Alexandria, Protrepticus 10; Origen, Contra Celsum 3.8, 10; Justin, 1 Apol 14; Didascalia Apostolorum 6.23. For comment, see Robert L. Wilken, Remembering the Christian Past (Grand Rapids: Eerdmans, 1995) 126-27. 
that unsophisticated Christians claimed that 'they alone... know the right way to live.'55 In response, Origen, who knew all about the empirical failings of the Christian communities, did not feel that he needed to disagree.56 For he knew communities of people who 'undertake the life which Jesus taught, the life which leads everyone who lives according to Jesus' commandments to friendship with God and fellowship with Jesus. ${ }^{\prime 57}$ It was these communities, catechised, baptised and changed, who were at the heart of Origen's apologetic and, arguably, of the spread of early Christianity as well. 58

\section{Pre-Constantinian Changes}

In the early fourth century Christianity, having lived through a period of intense persecution, began to spread for other reasons. Here we come to the dominant figure of the Emperor Constantine I. I shall deal more fully with his conversion elsewhere. But here I would like to observe briefly that, contrary to many scholars who date his 'conversion' from the time of his vision in 312, I am happier to view it as happening in 337 , in the last weeks of his life. It was then that he was finally willing to submit himself 'in the usual manner' to catechism and baptism. ${ }^{59}$ It is clear from our best source-

55Origen, Contra Celsum 3.55.

${ }^{56}$ For dysfunctional behaviour in the Christian communities, see Origen, Homily on Genesis 10.1; Homily on Jeremiah 4.3, 10.3.

57Origen, Contra Celsum 1.58.

58Origen, Contra Celsum 3.33. Cf. the comment of Marcel Borret in the introductory volume to his edition of Contra Celsum, Sources chrétiennes 227 (Paris: Cerf, 1976) 208.

59Pierre Batiffol, 'Les Etapes de la conversion de Constantin', Bulletin d'ancienne littérature et d'archéologie chrétienne 3 (1913) 264 remarked that Constantine was 'not even a catechumen'. F.J. Dölger, 'Die Taufe Konstantins und ihre Probleme', in idem, Konstantin der Grosse und seine Zeit (Freiburg im Breisgau: Herder'sche Verlagshandlung, 1913) 439, unconvincingly in my view, saw Constantine as a 'hearer'. For scholars who accept 312 as the time of the 'conversion' of Constantine, see T.D. Barnes, 'The Conversion of Constantine', Classical Views n.s., 4 (1985) 37191; Batiffol, 'Les Etapes'; Henry Chadwick, 'Conversion in Constantine the Great', in Derek Baker (ed.), Religious Motivation: Biographical and Sociological Problems for the Church Historian, Studies in Church History 15 
Eusebius's Life of Constantine-that these initiatory rites moved Constantine and changed him. As a result, he promised to change his lifestyle: 'I will prescribe to myself from this time such a course of life as befits [God's] service.' Henceforth until his death Constantine refused to wear the imperial purple.60 The effect of this is that prior to 337 Constantine's relationship with Christianity was awkward; it was that of a sympathetic outsider who was also in unprecedented senses an insider. This led Constantine to lavish privileges upon the Church and to place it on the road to dominance, but at the same time to express alienation from it.61 Although there are earlier examples of 'clinical baptisms' of ill people of all ages, Constantine was the first adult that we know of who deliberately chose it. His excuse for this was that he wished to delay baptism until he could be in the Jordan, 'wherein our Saviour, for our example, is recorded to have been baptised.' 62 As it turned out, Constantine made it only to Bithynia. But in his eleventh-hour baptism he left a new possibility-of being an unbaptised and uncatechised person who nevertheless viewed himself as 'Christian.'

Constantine's conversion has been variously assessed by historians: for Ramsay MacMullen it was a watershed, but for Henry Chadwick it was a mere 'ripple.' ${ }^{63}$ What were its effects upon catechism and baptism? For many Christian

(Oxford: Basil Blackwell, 1978) 1-13. For a recent interpretation by a liturgical historian, who sees Constantine as becoming a catechumen in 337, see E.J. Yarnold, 'The Baptism of Constantine', Studia Patristica 26 (1993) 95-191.

60Eusebius, Vita Constantini 4.62.

${ }^{61}$ Evidenced in his Oration to the Saints 11, 23, 26.

${ }^{62}$ Eusebius, Vita Constantini 4.62. This is the only recorded instance in which Constantine expressed interest in imitating Christ in his life. His iconography, on the other hand, freely appropriated images of Christ defeating Satan. See Rudolf Leeb, Konstantin und Christus: Die Verchristlichung der imperialen Repräsentation unter Konstantin den Grossen als Spiegel seiner Kirchenpolitik und seines Selbstverständnisses als christlicher Kaiser, Arbeiten zur Kirchengeschichte, 58 (Berlin: Walter de Gruyter, 1992) 49-51.

63MacMullen, Christianizing 102; Henry Chadwick, 'The Church of the Third Century in the West', in A. King and M. Henig (eds.), Roman West in the Third Century (London: British Archaeological Reports, 1981) 5. 
communities the effects of Constantine's conversion seem to have been considerable. For one thing, Constantine's conversion changed the social function of conversion in the lives of fourth-century people. Christian conversion had involved a process of resocialisation into a deviant group; now it entailed joining a group that was increasingly non-liminal.64 Second, Constantine's conversion and the events resulting from it changed the legal impetus for conversion. From 313, when Christianity was one of a palette of religious options (albeit one especially favoured by the Emperor), catholic Christianity by 392 had become the only legal public cult-infractions were punishable by law. ${ }^{65}$ Augustine records how, in Hippo, many people had been 'converted to Catholic unity by the fear of imperial laws.' 66 Third, imperial favour led to new motivations to convert: 'the hope of deriving some benefit from men whom he thinks he could not otherwise please, or to escape some injury at the hands of men whose displeasure... he dreads' are two reasons that Augustine mentioned.67 Resulting from all these is a fourth effect: the sheer quantity of converts inevitably posed new problems for Christian leaders. How could one truly engage with the convictions and lifestyle of the queues of catechumens if numbers precluded intimacy? By the middle of the fourth century, all of these effects had changed the situation in which catechism and baptism took place and in which people would observe Jesus' commandments.

In some churches, liturgical practice seems to have changed slowly. The communities in Egypt and Syria represented by the Canons of Hippolytus and the Testament of our Lord continued to have catechism, scrutinies of behaviour, and baptism largely in keeping with the practices of the Apostolic Tradition. ${ }^{68}$ In the 380s in Syria the community of the Apostolic

${ }^{64}$ Wayne Meeks, The Origins of Christian Morality: The First Two Centuries (New Haven: Yale University Press, 1993) 12, 21.

${ }^{65}$ Codex Theodosianus 16.10 .12 .

${ }^{66}$ Augustine, Ep 93.

${ }^{67}$ Augustine, De Cat Rud 9.

${ }^{68}$ Canons of Hippolytus 10-17; Testamentum Domini 2.1-6. The former may date from the mid-330s, the latter from the second half of the fourth century (but before 381); see Paul F. Bradshaw (ed.), The Canons of Hippolytus, Alcuin/GROW Liturgical Study 2 (Bramcote, Notts: Grove 
Constitutions still had a functioning catechumenate in traditional mould, which the community assumed would last for three years, reducible in case of 'diligence' .69

Elsewhere, however, things were changing more rapidly. Nothing indicates this better than the transformation in the catechumenate itself, changing it essentially. Admission to the new catechumenate, which had been stringent, now became relatively easy. Augustine records how he, as a child in the 350 s, became a catechumen. He had tasted the salt (of exorcism) and was signed with the cross; he also probably received the laying on of hands. ${ }^{70}$ Later, when bishop in Hippo, Augustine devised an elementary scrutiny and short catechism-his $D e$ Catechizandis Rudibus-to mark the reception of a new catechumen. Such a catechumenate could go on for years. Catechumens were now called 'Christians'. They could attend Sunday Bible readings and sermons, but they could not, of course, stay for the eucharists. Furthermore, they as a group were forbidden to attend the formal catechetical sessions for another group, the competentes, who were being prepared for baptism. So the catechumens had become a group within the widest confines of the Christian community who were distinguished by the fact that they were not being formally catechised! It was not, of course, that their leaders did not want them to be. Christian leaders pleaded with their flocks, footdragging like Constantine, to enrol themselves for catechism and baptism. They sought to arouse fear. Do it now, Augustine pleaded: 'This is the thing that kills many people, when they say, "Tomorrow, tomorrow...".71 Do it now, Gregory of Nazianzus appealed; do it 'while thy tongue is not stammering or parched...before there is a struggle between the man who would baptise thee and the man who seeks thy money...' ${ }^{72}$ Gregory addressed his listeners' hesitations and excuses:

Books, 1987) 7; Grant Sperry-White, The Testamentum Domini: A Text for Students, Alcuin/GROW Liturgical Study 19 (Bramcote, Notts: Grove Books, 1991) 6.

${ }^{69}$ Apostolic Constitutions 7.32.

${ }^{70}$ Augustine, Confessions 1.11.17.

${ }^{71}$ Augustine, Sermon 82.14.

${ }^{72}$ Gregory Nazianzus, Or 40.11 . 
involvement in the 'stain' of public affairs; being cut off from 'the pleasures of life'; status-the desire to be baptised by a bishop or the reluctance 'to be with a poor man'; fear-of 'the medicine of exorcism... [and] its length.' To those who were willing to be drowned into life, Gregory offered himself as 'the Director of your soul.'73

Those who responded to these appeals became part of an inner catechumenate which in the West were generally called the competentes ('those asking together') who collectively requested baptism. ${ }^{74}$ They still needed to be scrutinised for membership. In Jerusalem, for example, their sponsors were asked about 'all the serious human vices': 'Is this person leading a good life? Does he respect his parents? Is he a drunkard or a boaster?'75 In North Africa the comparable list included 'prostitutes, actors, or any disreputable person,' and especially those people involved in adultery. ${ }^{76}$ If they failed this scrutiny-which was rather undemanding by the standards of the Apostolic Tradition - they had to amend their ways, but many clearly passed. Numbers of course varied, but the annual intake of catechumens in Antioch in the 390s could easily reach a thousand. ${ }^{77}$ These were admitted to a short course of baptismal preparations. Its lengths varied: thirty days in Chrysostom's Antioch; the 'Lenten fast' in Cyril's Jerusalem; forty days in Leo's mid-fifth-century Rome.78 Together they submitted to a journey that was designed to lead to 'a second life and a purer lifestyle.'79

This was partly through the catechism which they received. According to Cyril, who catechised the multitudes in

\footnotetext{
${ }^{73}$ Gregory Nazianzus, Or 40.19-20, 26-27, 44. For other appeals to catechumens to present themselves for catechism and baptism, see Ambrose, De Elia et ieiunio; Caesarius of Arles, Sermon 200.

${ }^{74}$ In the East they were often called the photizomenoi (illuminands), in Rome the electi.

${ }^{75}$ Egeria, Travels 45.3 .

${ }^{76}$ Augustine, On Faith and Works 18.33.

${ }^{77}$ Auguste Piédagnel (ed.), Jean Chrysostome: Trois catéchèses baptismales, Sources chrétiennes 366 (Paris: Cerf, 1990) 43.

78John Chrysostom, Baptismal Instructions 9.29; Egeria, Travels 46.1; Leo, Sermons 58.1 .

${ }^{79}$ Gregory Nazianzus, Or 40.3 .
} 
Jerusalem between the 340 s and the 380 s, the subjects covered were 'pious doctrines and virtuous practices.' 80 Augustine similarly linked belief and behaviour: we teach 'not only what one must believe about Christ, but also how one must live who wishes to be joined to the body of Christ.' 81 This may have been the intention, but the balance of surviving teaching is overwhelmingly tilted towards belief. In thirteen lectures, Cyril painstakingly catechised through the Apostles' Creed, article by article. Elsewhere the Creed was only 'handed over' to the candidates on the second Sunday before their baptism; they were to memorise this and then make it their own by reciting it publicly in their baptismal rituals. Augustine urged his catechumens to have the Creed always in mind: to 'recite [it] in bed, think about in the streets, and not forget over your meals.' 82 This, we know, was the era in which people were fascinated by theology, in which orthodox formulations were being hammered out, and in which heresy in its many guises was deemed to be the greatest of evils. So Cyril's aim was to make his illuminands invincible against every heretical attempt.' 83

Other important parts of the catechising process in many places were the passing on of the Christian story and the teaching of the Lord's Prayer. Augustine placed great importance on salvation history; in his first lecture to the new catechumens, he gave them an hour-long survey of it. Others such as Augustine's disciple Quodvultdeus presented the salvation narrative at even greater leisure to his catechees in Carthage.84 In Syria, the community of the Apostolic

${ }^{80}$ Cyril, Cat 4.2 .

81 Augustine, On Faith and Works 9.14.

${ }^{82}$ Augustine, Sermon 215. Theodore of Mopsuestia urged his listeners to memorise the Creed so that they 'should continually meditate on the words of the Creed so that it may be strengthened in you and deeply fixed in your soul' as the Jews meditate on the Law (Theodore of Mopsuestia, Commentary on the Lord's Prayer and on the Sacraments of Baptism and the Eucharist, ed. A. Mingana, Woodbrooke Studies 6 [Cambridge: W. Heffer, 1933] 32-33).

${ }^{83}$ Cyril, Procat 10.

${ }^{84}$ Augustine, On Faith and Works 24-49; Quodvultdeus, Liber de promissionibus et praedictionibus Dei. 
Constitutions gave instructions about how God 'did glorify the saints in every generation' from Seth to Phineas. ${ }^{85}$ In Milan Ambrose similarly focused his attention on Old Testament patriarchs, devoting catechetical sermons to Abraham, Joseph and Jacob.86 For some reason, New Testament biographies seem to have been less useful to our catechists; we do not find catechetical sermons based on Paul-or Priscilla. But from the New Testament, the Lord's Prayer was becoming a central component of the catechetical process in both East and West. In Hippo it, like the Creed but a week later, was taught to the catechumens and memorised before their baptism. Augustine recommended this to his charges as a 'daily baptism' the saying of which probes our human sinfulness and is a means of forgiveness. 87

But what about the dimensions of lifestyle and praxis which had loomed so large in much earlier catechising? Fourthcentury catechists continued to insist that the behaviour on the part of the baptismal candidates must be renewed. Gregory of Nazianzus urged his hearers to 'work that which is good upon the foundation of dogma.'88 Augustine argued that one must 'say not only what one must believe about Christ but also how one must live who wishes to be joined to the body of Christ.' 89 But it is not always apparent how the behaviour that the catechists commended grew out of the beliefs which they attempted to inculcate. It also is noticeable that in the surviving catechetical literature the material devoted to behaviour is

${ }^{85}$ Apostolic Constitutions 7.39 .

86For the types of lessons that Ambrose derived from the patriarchs, see his De Ioseph, praefat: 'In him [Joseph] there shone forth above all the mark of chastity. In Abraham you have learned the undaunted devotion of faith, in Isaac the purity of a sincere heart, in Jacob the spirit's signal endurance of toils.' Ambrose's emphasis coincided with a change that was taking place in aristocratic circles throughout the empire: 'For the first time, the events of the Old Testament had become the true gesta maiorum of a large body of the Roman governing class' (Peter Brown, 'Saint Augustine's Attitude to Religious Coercion', in his Religion and Society in the Age of Saint Augustine [New York: Harper \& Row, 1972] 274).

87Theodore of Mopsuestia, Commentary 1ff.; Augustine, Sermons 56.14; $57.11 ; 59.7 ; 213.9$.

${ }^{88}$ Gregory of Nazianzus, Or 40.45.

${ }^{89}$ Augustine, On Faith and Works 9.14. 
vastly shorter than that devoted to belief. An extreme example of this imbalance is Gregory of Nyssa's Catechetical Oration, which at great length constructs what is the first systematic theology since Origen, but which has only isolated sentences about behaviour: 'the deformity of anger, or the passion of greed, or the unbridled and unseemly thought...'.90 Indeed, such comments as were there about practical matters generally came in lists such as the one I have just quoted; rarely were they presented with pastoral seriousness, in such a way that the hearers could take action upon them.

At times, the catechists could minimise the change being required of their listeners. Cyril reassuringly told his Jerusalem listeners that 'little are the things which thou art forsaking'-but after listing idle words, backbiting and not listening to backbiters he went on to more demanding matters such as forgiving others and diligently attending the church assemblies. ${ }^{91}$ Cyril devoted larger sections to food offered to idols, which apparently was of immediate concern to his Jerusalem listeners, and to apparel (4:27-28). Of great concern to Cyril was care for parents: 'The first virtue of godliness in Christians is to honour their parents... and with all their might to confer on them what tends to their comfort' (7:16). As to money, Cyril opposed the view that 'Riches, and gold, and silver are not, as some think, the devil's,' for they enabled Christian people to give to Jesus when they met him in those who were hungry or naked (8:6). In other communities practical concerns had to do with behaviour in bathhouses, the human propensity to adultery (to which Augustine was especially sensitive), and the 'chariot races and satanic spectacles in the hippodrome. ${ }^{\prime 92}$ Indeed, in Carthage virtually the only practical change that Quodvultdeus required of his baptismal candidates was to avoid the seducing spectacles in

\footnotetext{
${ }^{90}$ Gregory of Nyssa, Cat Or 40; Johannes Quasten, Patrology, III: The Golden Age of Greek Patristic Literature (Westminster, MD: Christian Classics, 1986) 262.

${ }^{91}$ Cyril, Cat 1.5-6.

${ }^{92}$ Apostolic Constitutions 1.9; Augustine, On Faith and Works 19.34; John Chrysostom, Baptismal Instructions 6.1.
} 
the amphitheatre, which rivalled the church as a focus for the city's people. .3

Did the catechists try to equip their people to obey the commandments which Jesus had given to his disciples? It seems that they did so less in the West than in the East. In Milan Ambrose based his daily teaching about 'right conduct' upon 'the lives of the patriarchs or the precepts of the Proverbs. ${ }^{94}$ His models and maxims were both derived from the Old Testament, not from Jesus. In Hippo Augustine of course drew images from the New Testament, but he increasingly based his catechesis upon the Decalogue; indeed, it was only with Augustine that the Ten Commandments came to occupy a central place in Christian moral instruction. ${ }^{95}$ In the East there was greater openness to using the teachings of Jesus as a basis for catechism. Gregory of Nyssa viewed it as essential that the catechumens 'be followers by the path of an exact imitation of him who leads the way to salvation. ${ }^{\prime} 96$ No doubt this sense that the way of Jesus could be followed and the teachings of Jesus could be obeyed was one reason why, in Antioch, John Chrysostom underlined with such passionate conviction Jesus' prohibition of swearing oaths. Chrysostom also, unusually in our catechetical materials, includes a lengthy section on 'How to Avoid Swearing'. 97 The contrast between East and West is demonstrated by the way that two writers handle the words of the Great Commission with which I began this lecture. In Antioch, Theodore of Mopsuestia began his

${ }^{93}$ Quodvultdeus, Sermones de symbolo ad catechumenos $1.2 ; 2.1 .4$. See R. de Simone, 'The Baptismal and Christological Catechesis of Quodvultdeus', Augustinianum 25 (1985) 273; Thomas M. Finn, 'It Happened One Saturday Night: Ritual and Conversion in Augustine's North Africa', Journal of the American Academy of Religion 58/4 (1990) 605.

${ }^{94}$ Ambrose, De Mysteriis 1.1.

${ }_{95}$ Gregory J. Lombardo (ed.), Augustine, On Faith and Works, Ancient Christian Writers 48 (New York: Newman Press, 1988) 85n; Augustine, Sermon 9.7, 13; Contra Faustum.

${ }^{96}$ Gregory of Nyssa, Cat Or 35.

97John Chrysostom, Baptismal Instructions 1.39-43; 9.36-47. For the early Christian rejection of all swearing on dominical grounds, see Alan Kreider, 'The Oath', in Everett Ferguson (ed.), The Encyclopedia of Early Christianity, rev. ed. (New York: Garland, 1997), forthcoming. 
catechetical lectures with the Great Commission, dwelling on the phrase 'And teach them to observe all the things I have commanded you.' Jesus said this, Theodore contended, so that 'alongside the doctrine of religion and right knowledge, we should endeavour to harmonise our lives with the divine commandments. ${ }^{\prime} 8$ In Milan, on the other hand, Ambrose also quoted Jesus' Great Commission, but only en passant-and he truncated it. He said, 'Teach [not make disciples of] all nations, baptise them in the name of the Father, and of the Son, and of the Holy Spirit,' but then he omitted the next phrase; teaching people to do what Jesus commanded was evidently not high on Ambrose's agenda. ${ }^{99}$ Even in the East, where there was a greater predisposition to give prominence to Jesus' teachings, there also could be a willingness to take the radicalism out of the dominical sayings. In Syria, for example, the compilers of the Apostolic Constitutions incorporated the 'two ways' teaching from the second-century Didache, but then added extenuating explanations: 'If any one give thee a stroke on thy right cheek, turn to him the other also' is immediately followed by the reassuring appendage: 'Not that revenge is evil, but that patience more honourable.' 100

\section{Late Fourth-Century Alternatives}

Thus far our examination has focused on matters of teaching. At this point, our focus turns to baptism itself. Baptism of course was the climax of all the preparations. It was in baptism that all one's prior sins were forgiven. Baptism wiped the slate clean; in Augustine's words, it was the 'bath of amnesty.'101 It also was the decisive defeat of satanic powers; in the waters the 'rulers of darkness' were drowned. 102 But as the fifth century progressed, the exorcisms-not the baptism proper-in the

\footnotetext{
98Theodore of Mopsuestia, Commentary 1 (ed. Mingana, 1).

${ }^{99}$ Ambrose, De Ioseph 12.71; De Iacob et vita beata 3.9 .

${ }^{100} \mathrm{Cf}$. Didache 1-2 with Apostolic Constitutions 7.2-3 on other issues as well: killing ('Not as if all killing were wicked, but only that of the innocent') and swearing ('But if that cannot be avoided, swear truly').

101 Augustine, Sermon 223.1.

${ }^{102}$ Idem, Sermon 223E.2. Cf. Cyril, Cat 1.3.
} 
minds of many came to be seen as the spiritual climax of the initiatory rite. Two centuries earlier, in the Apostolic Tradition, the pre-baptismal scrutiny had concentrated on whether the baptismal candidate had behaved like a Christian by honouring the poor and weak. In the fourth and fifth centuries, hagiographies still speak of the saints as responding to the needs of poor people. ${ }^{103}$ But by then the priorities of most communities had shifted, and the scrutiny came to be primarily an exorcist rite. It was awe-inspiring, terrifying, and humiliating, but it was very different from the experience of Justin or Cyprian. For them exorcism had been a means of liberation from the demonic forces which would keep them from espousing the teachings and priorities of Jesus; now it was a means of house-cleaning the new believers, but not of freeing them for new behaviour. 104

Was a different approach possible? There are two texts from late antiquity which indicate that other options were available. The first of these comes from Cappadocia in the 360s. Basil of Caesarea, in his On Baptism, set out to remind his friends of their baptismal commitments. ${ }^{105}$ Basil's foundational text was Matthew 28:19: he was concerned to 'make disciples of all nations.' 106 One must, he emphasised, 'first be made a

${ }^{103}$ Sulpicius Severus, Vita Martini 2; Hilary, Sermon on the Life of St Honoratus 5.

${ }^{104}$ Finn, 'It Happened One Saturday Night', 596-97; A. Dondeyne, 'La discipline des scrutins dans l'eglise latine avant Charlemagne', Revue d'histoire ecclésiastique 33 (1932) 9, 17; J.D.C. Fisher and E.J. Yarnold, 'The West from about $\mathrm{AD} 500$ to the Reformation', in Cheslyn Jones et al. (eds.), The Study of Liturgy, rev. ed. (London: SPCK, 1992) 145.

105Jeanne Ducatillon (ed.), Saint Basile de Césaré, Sur la Baptême, Sources chrétiennes, 357 (Paris: Cerf, 1989). There has been some debate about the authenticity of this text, and there had been an attempt for some years to see this as an 'ascetic' text and thus not applicable to the generality of Christians. On the genuineness of the text, see Ducatillon's summary (712) of the work of Jean Gribomont and Umberto Neri; as to its general applicability, see the judgement of Philip Rousseau (Basil of Caesarea [Berkeley: University of California Press, 1994] 192): '[Basil] maintained his convictions that the ideals he defended were suitable to all Christians, to be fulfilled within the Church in the broadest sense, rather than simply within more limited and segregated communities.'

${ }^{106}$ Basil, On Baptism 1.1.1 (subsequent citations are from this text). 
disciple before being admitted to baptism' (1:2:1). Basil did not challenge the order long traditional among Christians in which catechism preceded baptism; but one wonders how traditional Basil was in his teaching. His remarks are full of the stories, expressions and commandments of Jesus. He invited his hearers to become like children and to receive the Kingdom of God (1:2:2). Through their training they would be 'conformed to the teaching of our Lord Jesus Christ like wax to the mould' $(1: 2: 10)$. To experience this, Basil was convinced, the catechumens needed to experience baptism according to Paul's radical understanding in Romans 6 . They would need to be baptised into the death of Christ, to die to sin, their old selves, and the world. But then, by God's grace, they would be raised 'so that, as Christ Jesus was resurrected from death by the glory of the Father, so also we too may walk in a new life' (1:2:10). The signs of this would be lives 'conformed to the image of the Son', lives of cruciform distinctiveness. This was true for individual disciples and for them collectively: through their common life, rooted in obedience to Jesus, they would let their light shine before all people $(1: 2: 16,23)$. Through baptism Basil's catechumens would be able to die to anger and retaliation and rise to 'extend kindness even to our enemies, conforming ourselves to this commandment of our Lord Jesus Christ' (1:2:11). This would be brought about by the Holy Spirit, who works to activate 'the memory and teaching of the commandments of God which had been announced by the intermediacy of our Lord Jesus Christ' (1:2:20). In baptism, dying to the old, rising to the new, empowered by the Spirit, Basil's catechumens would be equipped 'to accomplish the word which... Jesus Christ our Lord added immediately to the mandate to baptise: "Teach them to observe everything that I have commanded you'" (1:2:24).

In North Africa, in the second decade of the fifth century, Augustine encountered another approach. 107 A group of lay people, whom he does not identify but whom he

${ }^{107}$ Gregory J. Lombardo (ed.), St. Augustine on Faith and Works, Ancient Christian Writers 48 (New York: Newman Press, 1988) 1, dates this work in 413. 
reported to be 'learned in the Scriptures', 108 were so cogent in their criticism of the Church's practice of baptism that they elicited from Augustine a detailed and largely unknown controversial work-On Faith and Works. We shall attempt to understand their arguments, recognising that they are-as is usual with heretics-refracted through the lens of the orthodox, in this case Augustine.

The critics, whom Augustine called 'our opponents,' argued, in contrast to Christian practice for the previous three centuries, that 'a man ought to be baptised first and then, after baptism, he can be instructed in regard to morals and right living.' 109 Those to be baptised should be taught only the rule of faith; only after baptism should it be explained that they should change their life for the better (1:1). The 'opponents' adduced a range of scriptural illustrations to argue their case, including those which I have mentioned early in this lecture: they devoted considerable attention to Peter at Pentecost and to Philip and the Ethiopian eunuch $(8: 12 ; 9: 14)$. But they went on: Paul taught nothing but Christ crucified as a precondition for baptism; Jesus taught a dual commandment, in which love for the Lord preceded baptism and love for the neighbour was for those already baptised; in the Exodus, the Israelites were in the Red Sea first and only then received the Law on Sinai (10:15-16; 11:17).

Augustine was outraged by the approach of the 'opponents'. As we know from his other writings, he was worried by the 'depraved who fill the church in body only,' and he did not want to add to their number. 110 Of course, a mortally ill person could be baptised 'after he has been instructed in the fewest possible words all that he must believe' (6:9). But for people in good health, what better time could there be to teach them how to live a Christian life than when they are 'all anxious and eager to receive this most salutary sacrament?' To be sure, there were bad as well as good in the church, but that did not mean that the discipline or vigilance of the Church

${ }^{108}$ Augustine, Retractions 2.37.

${ }^{109}$ Augustine, On Faith and Works 6.9. Subsequent citations references are from this work.

${ }^{110}$ Augustine, De Catechizandis Rudibus 11; Sermons 146.2; 224.1. 
ought to be relaxed or dispensed with' (2:3). It would be perverse for the church to imitate the devil by sowing cockle amongst the wheat (17:31)! Instead, the church should 'follow the way of Jesus, which is a way of moderation'; it should have 'Jesus as our guide and teacher' (5:7). But Augustine did not develop this line of thought; he did not like Basil elaborate a programme of catechism and baptism rooted in the teachings and way of Jesus. Instead he responded to the wide-ranging arguments of the 'opponents' one by one. Peter on Pentecost had first preached repentance; and in the case of Philip and the eunuch, 'we must not at all doubt that in [Philip's] preaching he talked about the manner of life one should lead and the morals one should have who believes in the Lord Jesus.' This, Augustine argued, was to 'preach Christ: to say not only what one must believe about Christ but also how one must live who wishes to be joined to the body of Christ...' $(8: 12 ; 9: 14)$. In Christ faith and morals mutually reinforced each other: one could not love the neighbour without loving God, and vice versa. Nor could one follow Jesus if one was, like the rich young man, inordinately attached to wealth (13:20). Or if one was attached to worst of all sins-adultery; 'if there is any sin for which a person should be refused baptism, that sin is adultery' (19:34). Therefore, Augustine contended, the church's tradition should be maintained. 'The church has always held' that instruction should precede baptism; that people of unacceptable professions ('prostitutes, actors or any other disreputable person') should be turned away unless they 'abandon their evil ways'; and that detestable sins such as 'drunkenness, avarice and calumny' should be taught against and that those who commit them should either change or be denied baptism (18:33). And if there were those who wished to reverse the church's traditional order-instruction before baptism-for the sake of introducing unrepentant adulterers into the church, let them be repudiated. In 413 C.E. the Church's traditional order seemed secure. 


\section{The Withering of Catechism}

It was not, of course. Within a century of Augustine's death this order had been reversed, not least because of Augustine's own theological contribution. For most Christians during the next millennium and a half baptism would precede instruction because infant baptism triumphed as the normal practice amongst Christians. It may have occurred to you that so far I have not referred to infant baptism. The reason is simple. Although at least from the mid-second century the baptism of infants can be documented, and in some Christian communities it was reasonably widely practised, especially apparently in North Africa, it always remained a less common practice than adult baptism. ${ }^{111}$ This must have been because the church continued to be involved in mission to people who were firstgeneration converts to Christianity. It also was because many churches seem not to have practised infant baptism, but the baptism of children if they were in danger of death.112 Chrysostom admitted that he practised 'even the baptism of children.' Gregory of Nazianzus urged that, if health permitted, children should not be baptised until at least the end of the third year; then they may begin 'to listen and to answer,' to know the outlines of Christian teaching and to 'begin to be responsible for their lives.' 113 And it is well-known that in the fourth century it was normal for children from Christian homes to be baptised when they were adults. ${ }^{114}$ But between the fifth and seventh centuries things changed. ${ }^{115}$ Imperial laws banning

${ }^{111}$ David F. Wright, 'The Origins of Infant Baptism-Child Believers' Baptism?' Scottish Journal of Theology 40 (1987) 1-23.

${ }_{112}$ Everett Ferguson, 'Inscriptions and the Origin of Infant Baptism', Journal of Theological Studies n.s., 30 (1979) 37-46; H. Leclercq, 'Néophyte', in Dictionnaire d'Archéologie Chrétienne et de Liturgie, vol. 12 (Paris: Letouzey, 1935) 1103-1105.

113John Chrysostom, Baptismal Instructions 3.6; Gregory of Nazianzus, Or 40.28 .

${ }^{114}$ For an impressive listing, see Dölger, 'Die Taufe Konstantins', 421-34.

${ }^{115}$ In the West infant baptism, according to one recent estimate, 'became the norm' between John the Deacon (c. 500) and Gregory II (715-31); see Thomas M. Finn, Early Christian Baptism and the Catechumenate: Italy, North Africa and Egypt, Message of the Fathers of the Church 6 (Collegeville, 
pagan worship and making infant baptism compulsory had their effect; whole communities were christianised through mass baptisms. ${ }^{116}$ Eventually the rites of initiation, which had always been based on the norm of adult baptism, now came to be altered; in the Gelasian Sacramentary of the eighth century the Western church gave expression of the new reality-the baptism of infants had become normal practice in Christendom. 117

So teaching would again come after baptism, as in the earliest days of the Christian movement. The question now was: would teaching take place at all? Although many of the liturgical usages of the ancient catechumenate-the scrutinies, the exorcisms-were incorporated in the rite of baptism, catechism itself disappeared. During the coming centuries, there would be no formal ecclesiastical instruction of children.118 This would be the responsibility of their sponsors, and pre-eminently of their parents. A writing attributed to seventh-century St. Eligius (d. 658) emphasised the responsibility of parents:

Know by memory the Symbol and the Lord's Prayer, and teach them to your children. Instruct and admonish the children, whom you have received as new-born from the baptismal fount, to live ever in the fear of God. Know that you have taken an oath on their behalf before God.119

The Apostles' Creed and the Lord's Prayer-these were the heart of the faith to be passed on from generation to generation

MN: Liturgical Press, 1992) 91-92. For another estimate, see A. Piédagnel, Jean Chrysostome: Trois catéchèses baptismales, 256-57.

116For compulsory baptism of infants, see the 529 law of Justinian I (CI 1.11.10); for a sample of forced conversion (in this case of Jews), see E.D. Hunt, 'St Stephen in Minorca: An Episode in Jewish-Christian Relations in the Early 5th Century A.D.', Journal of Theological Studies n.s., 32 (1982) 10623.

${ }^{117}$ Gelasian Sacramentary 1.26.3; 1.29.18; etc. See E.C. Whitaker (ed.), Documents of the Baptismal Liturgy, rev. ed. (London: SPCK, 1970) 167, 169. ${ }_{118}$ M.E. Jegen, 'Catechesis II (Medieval and Modern)', in New Catholic Encyclopedia (New York: McGraw Hill, 1967) vol. 3, 209.

${ }^{119}$ PL 87, 527, in Jegen, 'Catechesis II', 209. 
among those who were baptised and taught. ${ }^{120}$ But were people taught 'to observe all those things which I have commanded you'? They were evidently taught very little. And we might reflect, if second-century pagans who wished to become Christians had needed a well-planned and sustained programme of instruction and resocialisation (lasting up to three years), what did sixth-century Germans need? That they were taught so little gave immense power to the host culture, and resulted in which James $C$. Russell has called 'the Germanization of Christianity.'121

\section{Conclusions}

This survey taken us to the threshold of a thousand years of Christian civilisation in Europe which is customary referred to as Christendom. It was a civilisation in which everyone was baptised, and hence a civilisation which did not think it needed mission. Nor did it need effective catechism, for in a Christian civilisation everyone knew how to be Christian, if not how to be a disciple of Jesus. This world has now vanished, and its remnants are dissolving under the forces unleashed by the Reformation, the Enlightenment and globalisation. Although many institutions and assumptions of Christendom remain, our society is now like a spectrum of newly deregulated radio frequencies in which the 'signal' of Christianity competes with many others-perhaps handicapped by the fact that Christianity for so long had a monopoly of the airwaves. In this competitive situation, the early Christians, I believe, have special insights for us.

We have surveyed here the relationship between baptism and catechism in early Christianity, and the question of whether baptism or catechism should come first remains unresolved. The early Christians did not have a consistent

${ }^{120}$ Bede, Epistle to Egbert (5 November 734) 5, in J.N. Hillgarth (ed.), Christianity and Paganism, 350-700: The Conversion of Western Europe (Philadelphia: University of Pennsylvania Press, 1986) 161.

121James C. Russell, The Germanization of Early Medieval Christianity: A Sociohistorical Approach to Religious Transformation (New York: Oxford University Press, 1994). 
approach to this; we have seen that they changed from baptism before catechism to catechism before baptism-and then, as Christendom dawned, they changed back to the priority of baptism. Regardless of which order we choose, we must answer questions such as these. How should we teach apprentice Christians in our time? What should we teach them? What is the relative importance of theology, narrative, practice and experience? What is the role of rites in the initiatory process? What life changes do we expect or require? Approaches to these questions vary markedly between some who advocate inculturation and others who warn of the dangers of 'Christopaganism.'122 Whatever we decide, we must decide in light of the historical evidence which indicates that it is far easier to baptise than to make disciples.

Whatever we conclude about order, one impression lingers which I believe is worth pondering. From Jesus' Great Commission comes the summons to make disciples who will learn to do everything that Jesus commanded. As with baptism and catechism, our survey has revealed different approaches to the teachings of Jesus; but here there is no oscillation back and forth. From second-century Justin, for whom 'living as he taught' had suggested a rainbow of practical possibilities for transforming life, we have moved through the fourth and fifth centuries in which Jesus' teachings were progressively marginalised. ${ }^{123}$ We have noted the triumph, in the catechetical literature, of belief over behaviour; we also have noted the advent of power in the Christian world. Historically speaking it is, I believe, a truism: the more power Christians have the less authority Jesus has. In the gospels we again and again see Jesus catechising his disciples, and on no issue did he need to repeat his lessons more frequently than on power (e.g., Mk. 8:31ff; 9:33ff; 10:35ff). If Christians today, as disciples of Jesus in postChristendom, were to open ourselves to be catechised about power alone, surprising things might happen. We might find

${ }^{122}$ Aylward Shorter, Toward a Theology of Inculturation (London: Geoffrey Chapman, 1988); Alan R. Tippett, Tetsunao Yamamori and Charles R. Taber (eds.), Christopaganism or Indigenous Christianity? (Pasadena, CA: William Carey Library, 1975).

123Justin, I Apol 16. 
today that Jesus' 'doctrine' (didache, Mt. 7:28), as in first-century Galilee, is authoritative, hope-giving, and astounding to the crowds. 